\title{
1 Quantifying the system-wide recovery potential of waste in 2 the global paper life cycle
}

Stijn van Ewijk ${ }^{1 *}$, Joo Young Park ${ }^{2,3}$, Marian R. Chertow ${ }^{4}$

${ }^{1}$ Institute for Sustainable Resources, University College London (UCL), London, United Kingdom

${ }^{2}$ School of Management, Universidad de los Andes, Bogota, Colombia

${ }^{3}$ Graduate School of Energy and the Environment (KU-KIST Green School), Korea University

${ }^{4}$ School of Forestry \& Environmental Studies, Yale University, New Haven, United States

*Corresponding author: stijn.ewijk.13@ucl.ac.uk

\section{Highlights}

- The recovery potential of waste flows in the global paper life cycle is estimated

- An ideal life cycle features complete fulfilment of the recovery potential of waste

- The Recycled Input Rate (RIR) is 38\% in 2012 and $67-73 \%$ in the ideal life cycle

- The landfill intensity may be reduced from $331-473 \mathrm{~kg} / \mathrm{t}$ paper to $0-2.6 \mathrm{~kg} / \mathrm{t}$ paper

- The results reflect optimistic assumptions and maximum technical possibilities

\section{Abstract}

Waste from the global paper life cycle can be a lost economic opportunity and a risk to the natural environment and human health. This study assesses the recovery potential of major waste flows in the global paper life cycle to support improvements in material use. The "recovery potential" indicator shows the technical possibility for extracting value from waste through recycling and other forms of recovery. The potential is identified through a review of recovery technologies that are currently applied or likely to be commercially available by the year 2050. The analysis compares current material use in the global paper life cycle with an ideal scenario in which the recovery potential of all major waste flows is fulfilled. In the ideal scenario, the Recycled Input Ratio (RIR) is increased from $38 \%$ to $67 \%-73 \%$ and the landfill intensity is reduced from $331-473 \mathrm{~kg} / \mathrm{t}$ paper to 0 $2.6 \mathrm{~kg} / \mathrm{t}$ paper. The reduction in required landfill space is achieved mainly through increased consumer waste recycling. Better management of industrial waste from the paper sector has a rather limited impact on the RIR and landfill intensity. The conditions for successful recovery of waste are discussed separately. The analysis shows that the recovery potential indicator can be usefully applied to estimate potential improvements in complex material systems and the findings may inform policies for resource efficiency and the circular economy. 


\section{Introduction}

Sustainable waste and resource management should aim to reduce resource consumption and protect the environment and human health. Waste reuse and recovery enables the substitution of secondary materials in place of primary material inputs, avoids the harmful impacts of virgin material extraction and processing, and reduces the volume of waste going to landfill. For example, the use of paper sludge in cement kilns can reduce fuel and limestone consumption, avoid emissions from cement production and the impacts of limestone mining, and lower the amount of sludge or sludge ash to landfill. Waste may be reused within a facility, or across companies and industries through "industrial symbiosis" (Chertow 2000).

This study focuses on waste in the global paper life cycle. Paper is a key industrial sector in terms of energy consumption and environmental impacts. These impacts include forest degradation and deforestation, air emissions from power and heat generation, paper mill wastewater discharges, and emissions from landfill. In 2012, the consumption of paper products including newsprint, printing and writing paper, sanitary paper, and packaging was $399 \mathrm{Mt}$. The paper sector used approximately $347 \mathrm{Mt}$ of virgin fibre in mechanical and chemical pulping and $215 \mathrm{Mt}$ of discarded paper for recycling (Van Ewijk et al. 2017).

The global production and consumption of paper generate a large volume of solid waste including industrial waste (206 Mt) and end-of-life (E-o-L) discards (363 Mt) (Van Ewijk et al. 2017). The waste represents a lost economic opportunity and a risk to the natural environment and human health. Pulping and bleaching residues feature high pollutant loads (Kamali and Khodaparast 2015). Some fractions of the waste are hazardous and waste treatment can lead to pollution of air, water, and soil (Suhr et al. 2015). For example, land application of paper sludge ash poses a significant risk to groundwater through leaching of metals (Environment Agency 2015).

There are several reviews of waste generation and treatment in the pulp and paper sector. Bird and Talberth (2008) reviewed recovery options for various pulp and paper waste streams and examined waste treatment data for the United States. Monte et al. (2009) described waste management for pulp and paper in the European Union. Suhr et al. (2015) outlined best available techniques for the European pulp and paper sector, including ones for waste management. Finally, Bousios and Worrell (2017) reviewed alternative feedstocks and waste treatment options in the paper and board industry. However, none of these studies quantified the systemic benefits of using waste as a resource. 
Park and Chertow (2014) introduced a "reuse potential" indicator, which specifies the extent to which a waste can be used as a resource through a set of technologically available options. The reuse potential represents the usefulness of a waste with a score between 0 (complete waste) and 1 (complete resource). For example, a score of 0.45 indicates that $45 \%$ of the waste can be reused. The reuse potential shows what is technically feasible before other factors such as market demand and government regulation are considered (Park and Chertow 2014).

The present article adopts the logic of the "reuse potential" from Park and Chertow (2014) but uses the term "recovery potential" instead so as to be consistent with the definitions in the Waste Framework Directive (EC 2008). The term "recovery" includes recycling (substituting the original material), non-energy recovery (substituting other materials), and energy recovery (substituting fuels); these three activities represent the most widely observed uses of waste in the paper life cycle. The "reuse" of paper waste - using products or components again for the same purpose - is not included in the analysis. Waste that is not recovered is either incinerated without energy recovery or disposed of in landfill.

This study aims to answer the following question: how would the complete realization of the recovery potential of major waste streams in the global paper life cycle contribute to a circular economy by reducing waste to landfill and virgin material demand? The article makes a theoretical contribution by providing a testing ground to further refine the method proposed by Park \& Chertow (2014). This method has been applied only to the case of Coal Combustion By-products (CCBs) and deserves to be explored for other materials and complex material systems in particular. The final results are intended as a benchmark at the systems level and show what is possible at best. They also show what cannot be achieved even under the most optimistic assumptions. For example, there are limits to the avoidance of virgin inputs through increased recycling.

The article proceeds as follows. The next section discusses methods and data for calculating the recovery potential. Section 3 presents the results and compares current material flows with ideal material flows in two Sankey diagrams. Section 4 reflects on the limitations of the approach, the conditions for recovery, and the policy implications of the findings.

\section{Methods and data}

\subsection{Recovery potential indicator}

Park \& Chertow (2014) first suggested the reuse potential indicator and tested it for the case of coal combustion by-products (CCBs). For each type of CCBs - fly ash, FGD (flue-gas desulfurization) gypsum, bottom ash, and boiler slag - the authors estimated the amount that can be "technically" 
reused and recovered based on a set of commercially available reuse technologies in the United States. They showed that CCBs in the United States were $35-85 \%$ resource-like materials, depending on which reuse options are considered in the calculation (e.g. a more conservative estimate considered encapsulated uses of CCBs only while another considered all legally allowable uses).

This study takes a slightly different approach. It has a larger scope but less detail than Park \& Chertow (2014) and analyses all waste flows of the global paper life cycle. The assessment focuses on 1) the types of waste and the variety of waste recovery options and 2) the system-wide changes in material flows if the recovery possibilities are fully exploited. Two methods are used for assessing the recovery potential: a review of technologies that are currently available or potentially available by the year 2050 and an assessment of benchmark performance.

The review focuses on technologies and practices that may be commercially available by the year 2050 , and which safely substitute a virgin alternative. Information regarding waste recovery options is compiled from the academic and grey literature and includes technologies that are currently in the research and development phase and those that are commercially applied. The recovery potential is subsequently estimated based on an if-then statement. For example: if universal collection of endof-life discards were introduced, then $100 \%$ of waste paper from final consumption would be a resource.

The benchmark values are derived from the best performance observed at the mill, company, or country level. Such benchmark performance is often the result of the implementation of several technologies. Cases of best performance and practices are published in national statistics (e.g. for recycling) and company reports (e.g. industrial landfill rates). The following example describes a recovery potential based on benchmark performance: if global recycling operates at South-Korean standards, then $97 \%$ of end-of-life discards would be collected for recycling. Benchmark performance is equal to or less than the technically possible level of recovery.

\subsection{Current recovery in the paper life cycle}

The identification of a recovery potential first requires all data regarding the type and quantity of waste from the paper life cycle that is currently generated and recovered. Figure 1 displays the materials (rectangular boxes) and processes (rounded boxes) in the global paper life cycle with a detailed breakdown of solid waste generation and treatment. Waste (grey boxes) includes industrial waste and two categories of consumer waste: end-of-life discards and paper in sewage. The industrial waste is difficult to categorize because different data sources use different categories and 
waste from different processes may be mixed during waste (water) treatment at the paper mill.

Waste is nevertheless aggregated in the following categories based on their properties and volume.

1. End-of-life discards cover all the solid paper waste discarded from residential and commercial sectors, excluding the paper industry. It excludes net additions to stock and toilet paper, which ends up in sewage. It is often recycled but may be contaminated.

2. Paper in sewage consists of toilet paper that ends up in the sewer system and is treated as sewage. It is considered separately from end-of-life discards because the fibres are not available for recycling.

3. Black liquor is produced during the chemical (Kraft) pulping process and contains the lignin and hemicellulose separated from the cellulose for paper. It also contains inorganic chemicals used for pulping but only the organic fraction is discussed in this article. Black liquor has a high heating value and is virtually always used for on-site energy recovery (Naqvi et al. 2010).

4. Recycling sludge is generated during pulping and deinking of paper for recycling. It contains fibres, fillers, inks, adhesives, and inorganic materials. It is considered separately from other sludge because it has higher levels of contamination. It has a low heating value (Makinen et al. 2013; Monte et al. 2009).

5. Papermaking waste consists of losses from the conversion of pulp and non-fibrous material into paper and the conversion of paper into paper products. It is a clean and convenient source of paper for recycling (Stawicki and Read 2010).

6. Sludge and rejects cover the aggregate losses from chemical pulping (excluding black liquor and by-products) and mechanical pulping. They are suspended in wastewater, have fibrous content, and a low heating value (Suhr et al. 2015).

7. Causticizing waste consists of inorganic sludge generated in the chemical recovery cycle. It includes green liquor dregs, lime mud, and slaker grits. This waste has high alkalinity and may be contaminated (Bird and Talberth 2008).

8. Boiler ash results from organic waste combustion. The focus of this article is on wood and sludge ash and it excludes mixed ash from co-firing of, for example, coal and wood. Boiler ash has a high alkalinity and is cementitious (Bird and Talberth 2008).

The amount of waste generation and recovery are quantified based on a full material balance of the global paper life cycle established by Van Ewijk et al. (2017). This material balance only includes aggregate waste generation and treatment flows, which need to be separated into several smaller flows. 
- For waste generation, the flows are disaggregated in the following categories: chemical pulping by-products, sludge and rejects, causticizing waste, and boiler ash. The flows are largely based on waste intensities published by Suhr et al. (2015). The detailed estimation of waste generation is explained in Appendix A.

- For waste recovery, the fractions of recycling, energy recovery and non-energy recovery are estimated for each waste category. The data are drawn from a variety of sources covering several countries including the United States, Finland, and Canada. The detailed estimation of current recovery is explained in Appendix B.

167

The total quantity of mill waste used in this study is slightly different from Van Ewijk et al. (2017)

because by-products are subtracted from the total waste stream and lime makeup and boiler ash are added to the material balance.

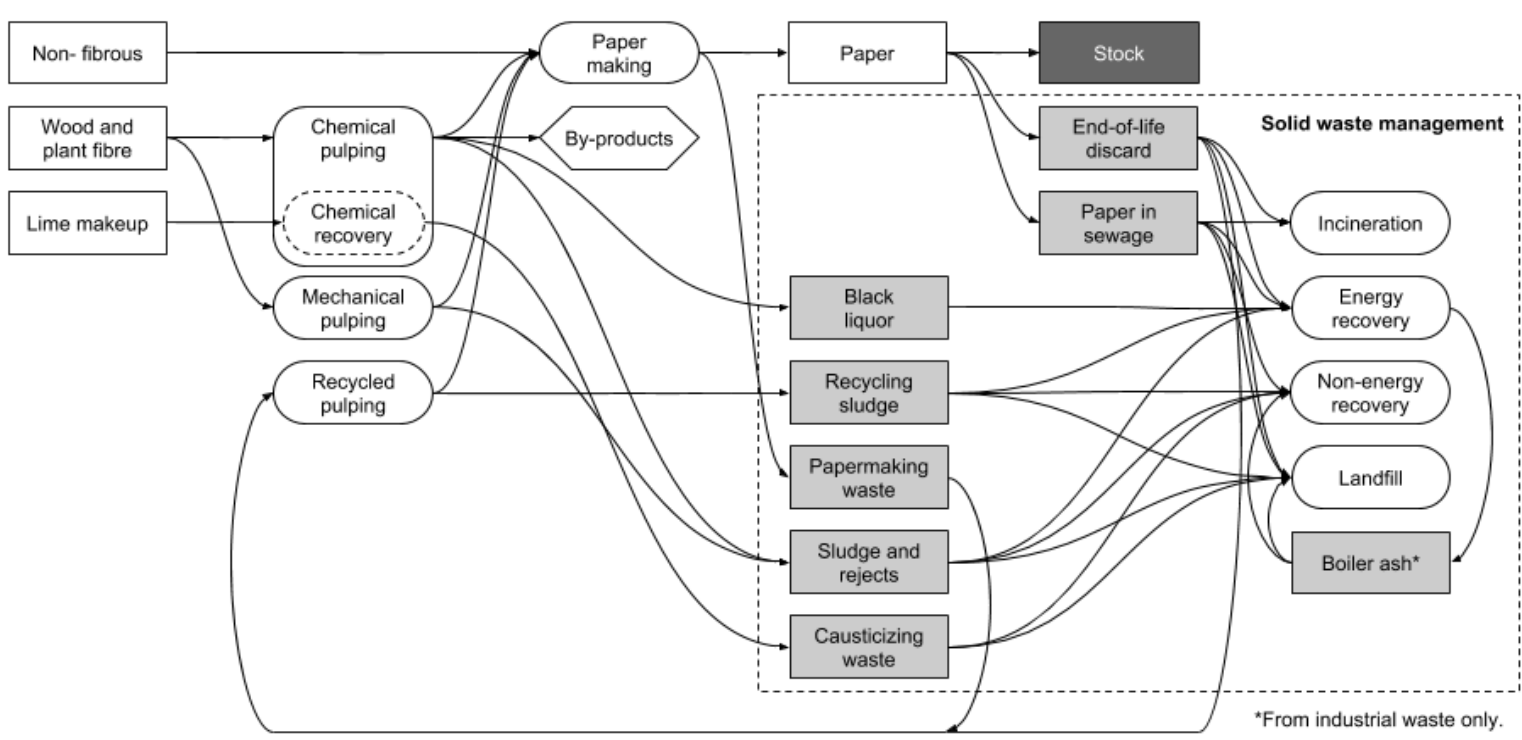

Figure 1: Flows (rectangular boxes) and processes (rounded boxes) in the paper life cycle.

170 A number of flows are not taken into account because they are very small, such as fly ash from the 171 recovery boiler (which is largely re-burned), minor lime residues, and salt cake from chlorine dioxide 172 production (Kinnarinen et al. 2016). Losses of pulping chemicals and ash from the combustion of 173 materials other than the aforementioned waste are also excluded, as well as any waste from 174 ancillary processes not described by Van Ewijk et al. (2017). Bark and other wood waste fall outside 175 the system boundary because they do not necessarily constitute process waste. When mills buy logs including bark (instead of chips) specifically for energy recovery purposes, the bark may be considered a fuel rather than an unintended process waste. 
Waste recovery is categorized into recycling, non-energy recovery, and energy recovery. Table 1 lists recovery options for waste from the paper life cycle, based on a review of the literature. The table matches the types of waste with the recovery options. It also shows the relevant properties of the waste, the process outputs, the avoided virgin alternative, example applications, and the stage of technological development for each recovery option. Substitution ratios between secondary and virgin material are not included since they strongly depend on the quality of the waste and the exact type of application. The substitution ratio for the largest waste flow, end-of-life discards, ranges between 0.9 and 1.7 t/t of virgin fibre (Van Ewijk et al. 2017).

The status of technological development of the recovery options is indicated as follows: 1 = research and development, 2 = pilot and demonstration, 3 = full-scale implementation. Only technologies that are firmly established (e.g. black liquor combustion) are given score 3. Each combination of waste flow and recovery option is in a unique stage of technological development. For example, composting of recycling sludge faces different challenges from composting of sludge and rejects. However, non-energy recovery operations are assigned a joint technology status 1-3, as no more detailed data could be obtained. Apart from combustion, all of the energy recovery options are either in the research and development stage or in the pilot and demonstration stage, depending on the type of waste that is recovered.

The overview of recovery technologies does not include pre-treatment of the waste. Drying is required for many forms of recovery of wet waste. Alternatively, Hydrothermal Carbonization (HTC) renders drying unnecessary and yields hydrochar that can be used for various energy and nonenergy recovery operations (Mäkelä et al. 2016; Alatalo et al. 2013; Kambo and Dutta 2015). Besides drying, several other pre-treatments may be needed to separate and purify the waste. The level of purification that can be achieved through pre-treatment technologies directly affects the recovery potential of the waste. For example, the separation and preparation of lime mud, green liquor dregs, and slaker grits may involve sedimentation, filtration, washing, dewatering, drying, and grinding. Technology choice affects waste properties such as $\mathrm{pH}$, water content, and level of impurities (Kinnarinen et al. 2016). 
Table 1: Waste recovery options for major waste flows in the global paper life cycle.

\begin{tabular}{|c|c|c|c|c|c|c|c|c|c|c|c|c|c|c|c|}
\hline $\begin{array}{l}\text { Type of } \\
\text { recovery } \\
\text { potential } \\
\end{array}$ & \begin{tabular}{|l|} 
Recovery \\
option or \\
application \\
\end{tabular} & $\begin{array}{l}\text { End-of-life } \\
\text { discards }\end{array}$ & $\begin{array}{l}\text { Paper in } \\
\text { sewage }\end{array}$ & Black liquor & $\begin{array}{l}\text { Recycling } \\
\text { sludge }\end{array}$ & $\begin{array}{l}\text { Papermaking } \\
\text { waste }\end{array}$ & $\begin{array}{l}\text { Sludge and } \\
\text { rejects }\end{array}$ & $\begin{array}{l}\text { Causticizing } \\
\text { waste }\end{array}$ & Boiler ash & $\begin{array}{l}\text { Relevant } \\
\text { property }\end{array}$ & $\begin{array}{l}\text { Process } \\
\text { outputs }\end{array}$ & Substitute & $\begin{array}{l}\text { Concept or } \\
\text { example }\end{array}$ & $\begin{array}{l}\text { Technology } \\
\text { status }\end{array}$ & References \\
\hline Recycling & Recycling & $x$ & & & & $x$ & & & & Fibre content & N/A & Virgin fibre & $\begin{array}{l}\text { Recycling of } \\
\text { fibres into new } \\
\text { paper products }\end{array}$ & 3 & $\mathrm{~N} / \mathrm{A}$ \\
\hline \multirow[t]{8}{*}{$\begin{array}{l}\text { Non-energy } \\
\text { recovery }\end{array}$} & Soil improver & & & & & & $x$ & $x$ & & Particle sizes & & \begin{tabular}{|l|l|} 
Various \\
organic \\
materials \\
\end{tabular} & $\begin{array}{l}\text { Road } \\
\text { construction, } \\
\text { erosion control } \\
\end{array}$ & \multirow[t]{8}{*}{$1-3$} & \multirow{8}{*}{$\begin{array}{l}\text { (Deviatkin } \\
\text { et al. 2014; } \\
\text { Bird and } \\
\text { Talberth } \\
\text { 2008; } \\
\text { Kinnarinen } \\
\text { et al. 2016; } \\
\text { Fytili and } \\
\text { Zabaniotou } \\
\text { 2008) }\end{array}$} \\
\hline & Compost & & $x$ & & $x$ & & $x$ & $x$ & $x$ & $\begin{array}{l}\text { Organic } \\
\text { content }\end{array}$ & & $\begin{array}{l}\text { Other green } \\
\text { waste }\end{array}$ & $\begin{array}{l}\text { Spreading on } \\
\text { farmland }\end{array}$ & & \\
\hline & Fertilizer & & $x$ & & $x$ & & $x$ & & $x$ & Nutrients & & Virgin $N, P, K$ & $\begin{array}{l}\text { Forest soil, } \\
\text { agricultural } \\
\text { land }\end{array}$ & & \\
\hline & Neutralizer & & & & & & & $x$ & $x$ & Alkalinity & & $\begin{array}{l}\text { Virgin } \\
\text { minerals, } \\
\text { mainly } \\
\text { limestone }\end{array}$ & $\begin{array}{l}\text { Acid Mine } \\
\text { Drainage } \\
\text { (AMD), } \\
\text { wastewater } \\
\text { treatment, soil } \\
\text { liming }\end{array}$ & & \\
\hline & Aggregate & & & & $x$ & & $x$ & $\mathrm{x}$ & $x$ & $\begin{array}{l}\begin{array}{l}\text { Particle size } \\
\text { and shape }\end{array} \\
\end{array}$ & & $\begin{array}{l}\begin{array}{l}\text { Virgin } \\
\text { aggregate }\end{array} \\
\end{array}$ & $\begin{array}{l}\text { Brick, road } \\
\text { surface }\end{array}$ & & \\
\hline & Admixture & & $\mathrm{x}$ & & $x$ & & & $\mathrm{x}$ & $x$ & $\begin{array}{l}\text { Cementitious } \\
\text { properties }\end{array}$ & & $\begin{array}{l}\text { Portland } \\
\text { cement }\end{array}$ & $\begin{array}{l}\text { Cement } \\
\text { production, } \\
\text { concrete } \\
\text { blocks }\end{array}$ & & \\
\hline & Filler & & & & $x$ & & $x$ & & & Fibre content & & Virgin fibre & $\begin{array}{l}\begin{array}{l}\text { Fibreboard, } \\
\text { particle boards }\end{array}\end{array}$ & & \\
\hline & Adsorbent & & & & $x$ & & $x$ & $x$ & $x$ & $\begin{array}{l}\text { Adsorption } \\
\text { capacity }\end{array}$ & & 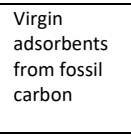 & $\begin{array}{l}\text { Flue gas } \\
\text { desulfurization, } \\
\text { adsorption of } \\
\text { odours and } \\
\text { colours } \\
\end{array}$ & & \\
\hline \multirow[t]{4}{*}{$\begin{array}{l}\text { Energy } \\
\text { recovery }\end{array}$} & Combustion & & $x$ & $x$ & $x$ & & $x$ & & & \multirow[t]{4}{*}{$\begin{array}{l}\text { Water } \\
\text { content, ash } \\
\text { content, } \\
\text { heating value }\end{array}$} & $\begin{array}{l}\text { Direct heat, } \\
\text { ash }\end{array}$ & $\begin{array}{l}\text { Biomass or } \\
\text { other fuels, } \\
\text { minerals } \\
\text { such as sand, } \\
\text { other ash }\end{array}$ & $\begin{array}{l}\text { Incineration } \\
\text { with or } \\
\text { without } \\
\text { auxiliary fuels } \\
\text { such as coal } \\
\end{array}$ & 3 & \multirow{4}{*}{$\begin{array}{l}\text { (Ouadi et al } \\
\text { 2013; Naqvi } \\
\text { et al. 2010; } \\
\text { Ekstrand et } \\
\text { al. 2013; } \\
\text { Deviatkin et } \\
\text { al. 2014; } \\
\text { Stocica at al. } \\
\text { 2009; Fytili } \\
\text { and } \\
\text { Zabaniotou } \\
\text { 2008) }\end{array}$} \\
\hline & $\begin{array}{l}\text { Anaerobic } \\
\text { digestion }\end{array}$ & & $x$ & & $x$ & & $x$ & & & & $\begin{array}{l}\text { Methane } \\
\text { fuel gas, } \\
\text { digestate }\end{array}$ & $\begin{array}{l}\text { Natural gas, } \\
\text { virgin } \\
\text { fertilizer }\end{array}$ & $\begin{array}{l}\text { Breakdown by } \\
\text { microorganism } \\
\text { s without } \\
\text { oxygen }\end{array}$ & \multirow[t]{3}{*}{$1-2$} & \\
\hline & Gasification & & $x$ & $x$ & $x$ & & $x$ & & & & Syngas, ash & $\begin{array}{l}\text { Natural gas, } \\
\text { minerals } \\
\text { such as sand, } \\
\text { other ash }\end{array}$ & $\begin{array}{l}\text { High- } \\
\text { temperature } \\
\text { conversion } \\
\text { with limited } \\
\text { oxygen }\end{array}$ & & \\
\hline & $\begin{array}{l}\text { Pyrolysis } \\
\end{array}$ & & $x$ & & $x$ & & $x$ & & & & $\begin{array}{l}\begin{array}{l}\text { Pyrolysis oil, } \\
\text { chemicals, } \\
\text { charcoal }\end{array}\end{array}$ & $\begin{array}{l}\text { Fossil fuels } \\
\text { and virgin } \\
\text { minerals }\end{array}$ & $\begin{array}{l}\text { High- } \\
\text { temperature } \\
\text { decomposition } \\
\text { without } \\
\text { oxygen } \\
\end{array}$ & & \\
\hline
\end{tabular}


The calculation of the recovery potential of each waste flow is based on four main assumptions. First, all known technologies and practices, listed in Table 1, are assumed to be further developed over the next few decades and to become commercially available by 2050 . Second, it is expected that improved contamination control allows for functional and safe use of waste in non-energy recovery and energy recovery applications. Significant efforts would be required to achieve this in practice, including prevention (e.g. substituting chemicals or using alternative materials), removal (e.g. better deinking technology), constraining (e.g. encapsulated use of waste), and destruction of contaminants (e.g. thermal treatment). Third, for recycling, contamination is assumed to affect the yield ratio of recycled pulping, because of the following issues.

- Increased recycling implies the use of waste paper that is not currently recycled because of its comparatively low quality.

- With increased recycling, contaminants may accumulate in the paper life cycle and reach higher concentrations.

- A higher recycled content for all grades, including high-quality ones, leads to more strict deinking requirements.

These issues may be partly addressed by introducing more separate collection of paper instead of commingled collection (Miranda et al. 2013). However, increased recycling will inevitably require more thorough deinking and cleaning of recycled pulp, which reduces the pulping yield. Based on Van Ewijk et al. (2017), the recovery potential calculation applies a lower pulping yield (73\% instead $81 \%)$ under complete fulfilment of the potential for recycling. Finally, the calculation excludes any restrictions on demand for waste or waste-based products. In reality, demand may be limited because of the limited number of recovery facilities, the transport costs of obtaining the waste, or attitudes towards waste and waste-based products. These factors, as well as contamination issues, are discussed further in Section 4.

\section{Results}

The results regarding the recovery of the individual waste flows are presented in table 2 . It shows the absolute quantities of waste generated in 2012 as well as the fractions (between 0 and 1 ) of current recovery, benchmark recovery, and potential recovery. The benchmark recovery fraction and the recovery potentials are derived from the literature, reports, and the information in table 1 . They are calculated based on the following assumptions. 
1. End-of-life discards can be fully recycled but with aforementioned impacts on the recycled pulping yield. The benchmark collection rate was $91 \%$, as reported in South Korea between 2012-2014 (FAO 2016) ${ }^{1}$. Using the global parameters for papermaking waste, net additions to stock, and paper in sewage, this implies a fraction of 0.97 of end-of-life discards to recycling (see Appendix C for the full calculation). The South-Korean performance is very close to the potential for recycling of 1.00 for end-of-life discards. At the same time, it is technically possible to use all paper waste for energy recovery. The combined potential is thus 1.00 .

2. Paper in sewage may receive any treatment suitable for sewage sludge. This includes a large variety of non-energy recovery and energy recovery options. The role of agricultural use is limited: EU legislation prohibits deposition of untreated sludge on land and many countries banned sludge application altogether (Milieu Ltd. and WRc and RPA 2013). The recovery potential for non-energy recovery and energy recovery and the benchmark are 1.00 because various countries report zero sewage sludge to landfill (Milieu Ltd. and WRc and RPA 2013). It should be noted that energy outputs from energy recovery can be low due to the high energy demand for drying (Fytili and Zabaniotou 2008).

3. Black liquor is already always used to recover cooking chemicals, by-products, and energy. The recovery potential calculation for black liquor considers using it more efficiently through gasification. With this technology, black liquor is not burnt directly but converted to a fuel gas (BLG) that is burned in a gas turbine with combined cycle (BLGCC). Alternatively, the gas is turned into a motor fuel (BLGMF). BLG is likely to become a key technology and a competitive option in the future (IEA ETSAP 2015; Naqvi et al. 2010). Both BLGCC and BLGMF have been demonstrated in Sweden and the US (European Biofuels Technology Platform 2016; NETL 2016). The energy recovery potential for BLG is assumed to be 1.00 .

4. Recycling sludge may be used for non-energy recovery and energy recovery. Data from individual mills show that zero landfill is achievable for deinking sludge (Deviatkin et al. 2014). Energy recovery options include combustion, anaerobic digestion (AD), gasification and pyrolysis. Full-scale facilities exist for anaerobic digestion of recycling sludge (Meyer and Edwards 2014) and there are pilot projects for gasification and pyrolysis of recycling sludge (Universiteit Twente 2015; Ouadi et al. 2012, 2013). Non-energy recovery technologies

\footnotetext{
${ }^{1}$ Based on average collection and consumption in 2012-2014. Consumption was calculated as production + imports - exports. Singapore and Iceland had even higher collection rates but their volumes of collected paper are rounded estimates and therefore deemed less reliable. RISI, a major private sector data provider in the paper sector, is cited in several news outlets to calculate the South Korean collection rate at $92.1 \%$ in 2013.
} 
suitable for recycling sludge include use as compost, fertilizer, aggregate, admixture, filler, or adsorbent. The combined recovery potential is therefore 1.00 .

5. Papermaking waste is a clean and convenient source of recyclable material and can be fully recycled according to Van Ewijk et al. (2017) and Stawicki and Read (2010). The current recovery level and the benchmark therefore equate to a recovery potential of 1.00.

6. Sludge and rejects can be used in a variety of ways but hardly any treatment data are

Some waste can be used for both energy recovery and non-energy recovery. The assumed split between the two options, shown in the last column of table 2 , is necessary to establish a complete 
2050 is based on the relative sizes of the same fractions in $2012^{2}$. For end-of-life discards, recycling is preferred over energy recovery. Based on Wiechmann et al. (2013), incineration with energy and phosphorus recovery is considered to be most attractive for paper in sewage, and is categorized as energy recovery.

Table 2: Waste recovery and recovery potential for major waste flows in the global paper life cycle.

\begin{tabular}{|c|c|c|c|c|c|c|}
\hline Waste flow & $\begin{array}{l}\text { Quantity in } \\
2012 \text { (Mt) }\end{array}$ & $\begin{array}{l}\text { Type of } \\
\text { recovery }\end{array}$ & $\begin{array}{l}\text { Current } \\
\text { recovery }\end{array}$ & Benchmark & $\begin{array}{l}\text { Recovery } \\
\text { potential }\end{array}$ & $\begin{array}{l}\text { Recovery in } \\
2050\end{array}$ \\
\hline \multirow{2}{*}{$\begin{array}{l}\text { End-of-life } \\
\text { discards }\end{array}$} & \multirow[t]{2}{*}{351} & Recycling & 0.55 & 0.97 & 1.00 & 1.00 \\
\hline & & Energy recovery & 0.12 & N/A & 1.00 & 0.00 \\
\hline \multirow[t]{2}{*}{ Paper in sewage } & \multirow[t]{2}{*}{12} & Energy recovery & 0.12 & \multirow[t]{2}{*}{1.00} & \multirow[t]{2}{*}{1.00} & 1.00 \\
\hline & & $\begin{array}{l}\text { Non-energy } \\
\text { recovery }\end{array}$ & 0.40 & & & 0.00 \\
\hline Black liquor & 152 & Energy recovery & 1.00 & 1.00 & 1.00 & $\mathrm{~N} / \mathrm{A}$ \\
\hline \multirow[t]{2}{*}{ Recycling sludge } & \multirow[t]{2}{*}{41} & Energy recovery & 0.08 & \multirow[t]{2}{*}{1.00} & \multirow[t]{2}{*}{1.00} & 0.14 \\
\hline & & $\begin{array}{l}\text { Non-energy } \\
\text { recovery }\end{array}$ & 0.50 & & & 0.86 \\
\hline $\begin{array}{l}\text { Papermaking } \\
\text { waste }\end{array}$ & 21 & Recycling & 1.00 & 1.00 & 1.00 & N/A \\
\hline \multirow{2}{*}{$\begin{array}{l}\text { Sludge and } \\
\text { rejects }\end{array}$} & \multirow[t]{2}{*}{5.6} & Energy recovery & 0.25 & \multirow[t]{2}{*}{1.00} & \multirow[t]{2}{*}{1.00} & 0.50 \\
\hline & & $\begin{array}{l}\text { Non-energy } \\
\text { recovery }\end{array}$ & 0.25 & & & 0.50 \\
\hline $\begin{array}{l}\text { Causticizing } \\
\text { waste }\end{array}$ & 4.5 & $\begin{array}{l}\text { Non-energy } \\
\text { recovery }\end{array}$ & 0.25 & $0.46^{*}$ & $0.75+-0.25$ & N/A \\
\hline Boiler ash & 0.4 & $\begin{array}{l}\text { Non-energy } \\
\text { recovery }\end{array}$ & 0.50 & 1.00 & 1.00 & N/A \\
\hline
\end{tabular}

*For green liquor dregs and lime residues together (Nurmesniemi et al. 2007). Green liquor dregs may be fully recovered (Mondi 2016). No individual benchmark data are available for lime residues and slaker grits.

The overall changes in material flows under fulfilment of the recovery potential can be clarified with Sankey diagrams. The first use of the Sankey diagram by its originator was to depict conventional and ideal energy flows in a steam engine (Schmidt 2008; Sankey 1898). Figure 2 follows the same logic and shows the material flow pattern in the global paper life cycle in 2012 and the potential flow pattern based on fulfilment of the recovery potential. The demand for virgin materials is recalculated by keeping the ratios between chemical and mechanical pulp and between non-fibrous and fibrous inputs (pulp) constant. Because of the increase in recycled pulp, the fractions of both mechanical and chemical pulp are approximately halved. The flows are normalized to 100 units of consumption (for the base year 1 unit $=4 \mathrm{Mt}$ ). Appendix $\mathrm{D}$ provides detailed material balances and specifies generation and treatment quantities for all eight waste flows. It should be noted that the

\footnotetext{
${ }^{2}$ For recycling sludge, the fraction of energy recovery is $0.08 /(0.08+0.50)=0.14$. The fraction of non-energy recovery is $0.50 /(0.08+0.50)=0.86$.
} 

relatively high yield recycled pulping (73-89\%) displaces low yield chemical pulping (40-55\%). Boiler ash generation is much higher because of increased levels of energy recovery.

322 

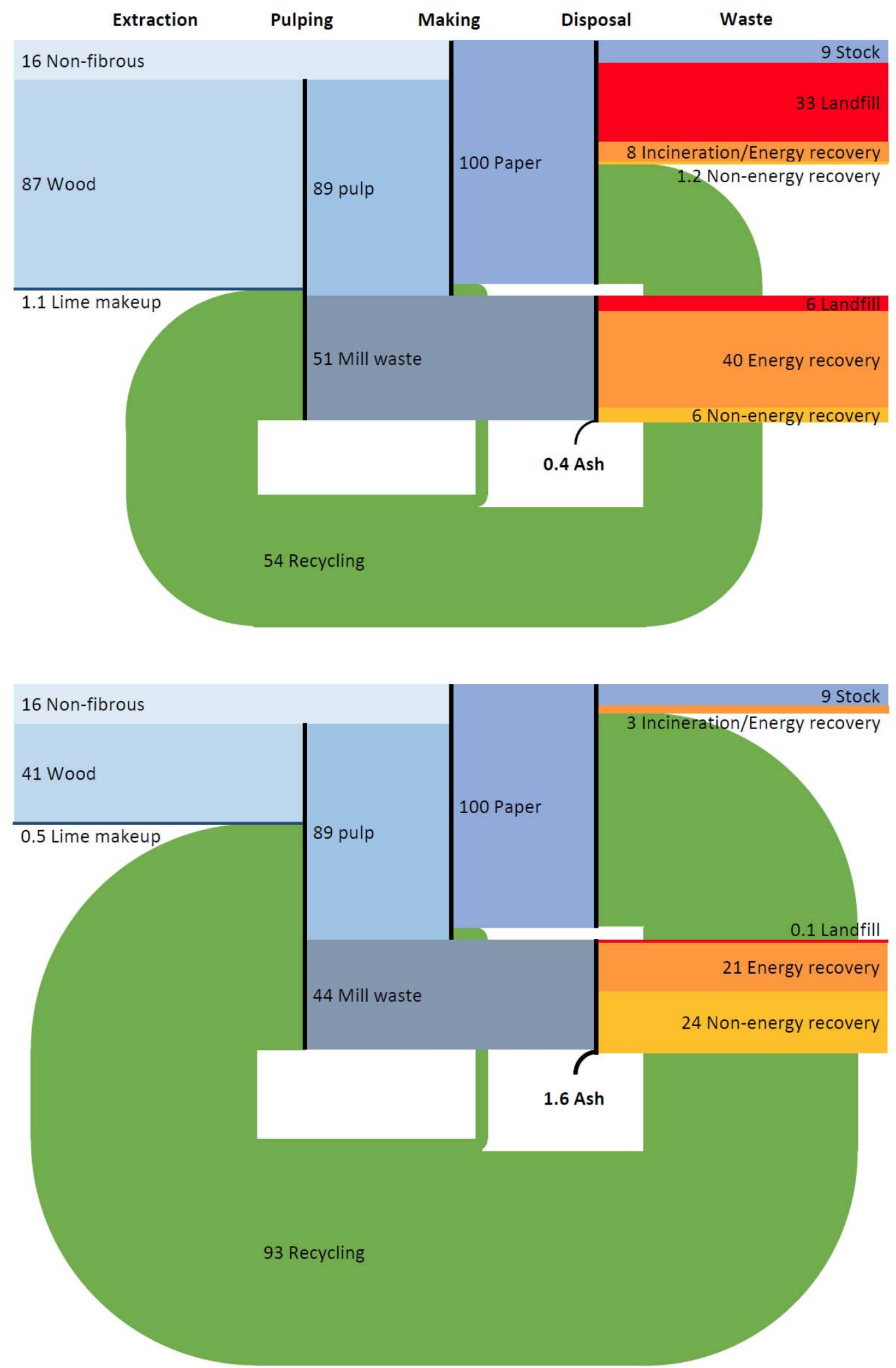

Figure 2: Current (above) and ideal (below) global paper life cycle. The flows are normalized to 100 units of consumption (for the base year 1 unit $=4 \mathrm{Mt}$ ). 
The ideal flow pattern improves performance in two ways. First, a large increase in recycling leads to a large reduction in landfill. Recycling dominates the ideal scenario because end-of-life discards is the largest waste flow in the system and almost all of it is recycled. Second, the demand for virgin fibre is approximately halved which implies a proportional reduction of upstream environmental impacts. The Recycled Input Rate (RIR), which measures the fraction of paper for recycling in the total fibrous inputs, is almost doubled from $38 \%$ to $67-73 \%$; the variation depends on the fraction of addition to stock (0.06-0.12), which is not available for recycling (Van Ewijk et al. 2017). In the ideal scenario, a significant amount of virgin materials is still required, mainly because fibres are lost in the recycling process.

Wood is not the only virgin input that is avoided through waste recovery. The recovery of waste other than end-of-life discards or papermaking waste substitutes for various raw materials including virgin phosphorus, Portland cement, and fossil fuels. Recovery of industrial waste outside of the system boundary is much higher in the ideal scenario. At the same time, increased recycling reduces energy recovery of end-of-life discards in MSW incineration plants. The total impact of recovery of waste outside of the global paper life cycle is a function of the substitution potential of the waste. The extent to which waste materials can substitute for virgin inputs depends among others on waste properties, process efficiencies, and market conditions (Vadenbo et al. 2017).

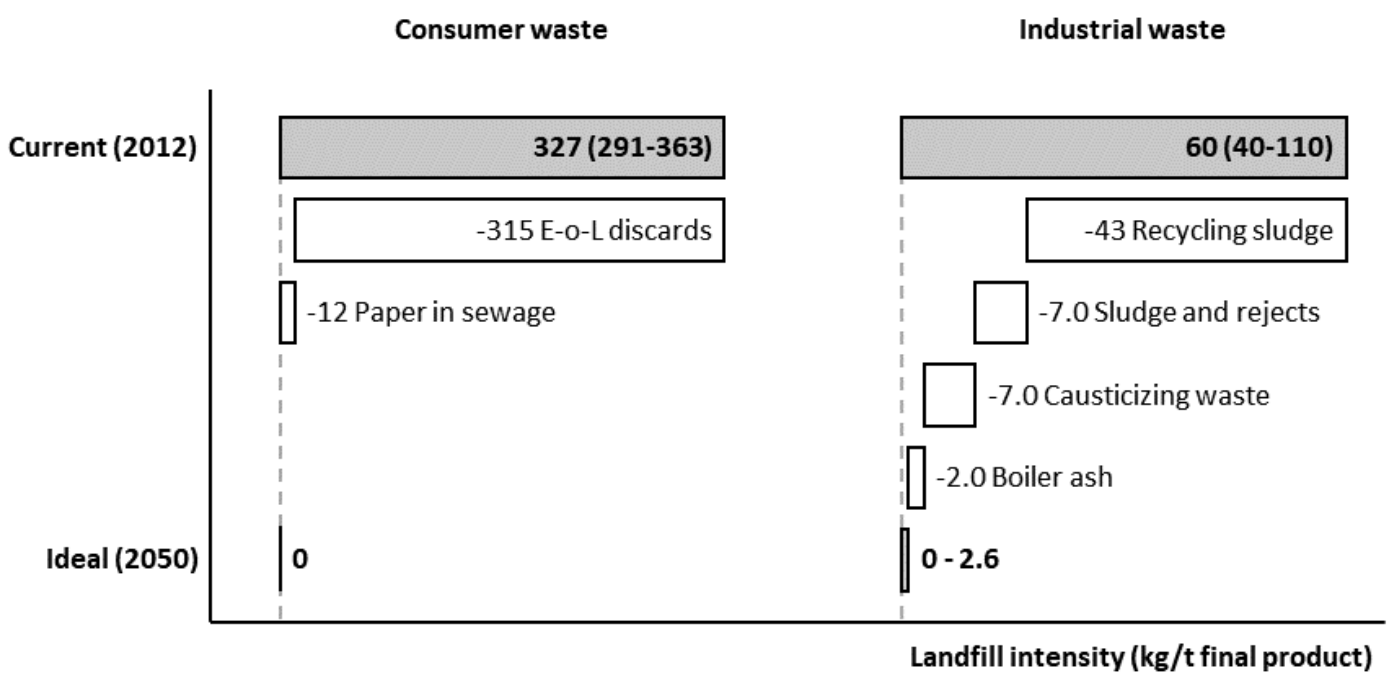

Figure 3: Contributions to a reduction in landfill intensity.

Figure 3 shows the current and ideal landfill intensity of consumer waste (E-o-L discards and paper to sewage) and industrial waste (all other waste streams). For consumer waste, the uncertainty range for current performance is based on the extent of addition to stock; for industrial waste, the uncertainty range is based on the differences in industrial waste generation data (Van Ewijk et al. 
2017). The figure indicates to what extent diversion of individual waste flows contributes to the overall reduction in landfill in the ideal scenario. The largest improvement is through diverting E-o-L discards and recycling sludge from landfill. The overall landfill rate per tonne of final product decreases dramatically to only $0-2.6 \mathrm{~kg} / \mathrm{t}$. In the ideal scenario, the waste to landfill consists of causticizing residuals only. Near zero landfill may seem impracticable but a selection of paper mills in Europe already claims landfill rates as low as $14 \mathrm{~kg} / \mathrm{t}$ (CEPI 2013). UPM, a major paper producer, aims for zero landfill status by 2030 and claims to have achieved this already for several mills (UPM 2016).

\section{Discussion}

\subsection{Limitations of the approach}

This study assessed the system-wide changes in material flows when fulfilling the recovery potential of major waste streams in the global paper life cycle. In the "ideal" scenario, all recovery options that are expected to be commercially available by 2050 , are implemented. This was shown to reduce virgin fibre requirements by approximately half and reduce waste to landfill to almost zero. However, due to various limitations, it was not possible to provide precise estimates that could directly inform decision-making. The lack of data on technology status and waste quality meant that only a single optimistic scenario could be constructed. The present results are suitable for long-term scenario analysis but do not directly indicate currently available opportunities.

More detailed data regarding the quantity and quality of waste, the status of the technologies, and the waste properties required for successful recovery may be gathered for smaller spatial scales or a more limited number of waste streams. The data collection process revealed that country data is more widely available than global data; it should therefore be possible to formulate more precise national recovery potentials. It should also be noted that in the present article, the extrapolation of country data to the global level introduced bias. However, all national data are from countries with large pulp and paper sectors that have a significant share in the global pulp and paper market (Finland, United States, and Canada).

The optimization of the material flows did not consider the effect of waste generation and treatment on supply and demand of electricity and heat. On-site energy recovery is an efficient and attractive means of powering pulp and paper activities but the ideal paper life cycle features a much smaller role for energy recovery. This outcome is generally consistent with the waste hierarchy but may not actually be most beneficial for the case of the pulp and paper industry. It is also important to account for the heating value of the waste; only black liquor has a significant heating value and 
energy recovery from sludge makes a relatively small contribution to electricity and heat supply. At the same time, a shift from virgin to recycled pulping lowers energy demand, though high deinking requirements can reduce the energy savings of recycled pulping compared to chemical pulping.

Not all non-energy recovery options are unambiguously beneficial. Land application of sludge could fertilize soils but may sometimes leave the soil quality unchanged. In the latter case, the waste is diverted from landfill but the recovery operation does not replace virgin fertilizer. Worse even, the sludge may contaminate and negatively affect the soil quality, which is why many countries discourage or prohibit these activities (Milieu Ltd. and WRc and RPA 2013). Another concern is the secondary waste resulting from waste recovery. For example, the use of waste as an adsorbent is a low added value application, which generates an equal amount of waste after adsorption. This waste then still needs to be dealt with and is probably incinerated. Ideally, the waste is recovered in such a way that another use is still possible afterwards. In other words, recovery should try to avoid a "dead end" at which only incineration or landfill remains.

The calculations were based on various optimistic assumptions and moving toward the ideal scenario would require the right conditions to be realized. For example, the analysis assumed universal collection for end-of-life discards, and hence fulfilling the recovery potential would first require establishing the relevant infrastructure. An important barrier to recovery is a lack of knowledge of recovery options and this article helps to overcome this barrier by presenting a quantified recovery potential. Other conditions for recovery can be categorized as technological (technological development), environmental (contamination and toxicity), economic (supply, demand and transport), and social (social and cultural context). Due to a lack of data, these conditions could not be incorporated in the quantitative analysis, but their relevance is further explained in the next section.

\subsection{The conditions for recovery}

\subsubsection{Technological development}

The assessment focuses on technologies that are likely to be available by 2050 . Technological development is particularly important for advanced energy recovery technologies. Gasification (of black liquor or sludge) and pyrolysis (of sludge) are not currently commercially applied. These technologies are potentially more energy-efficient than combustion but require further development for large-scale applications. Moreover, energy recovery technologies are capital intensive. The shift from combustion to gasification of black liquor needs to fit the investment cycle. Worldwide, many recovery boilers will become obsolete in the next 15 years. As gasification is 
considered a promising technology, these old boilers may be replaced with gasification units (Naqvi et al. 2010).

413 Energy recovery of waste flows other than black liquor is challenging, because of their high water content, high ash content, and low heating values. Older combustion methods require co-firing with other fuels but more efficient fluidized bed boilers do not require co-firing. For gasification or pyrolysis, the sludge first needs drying, which partly offsets the gains from a more efficient energy recovery process (Stoica et al. 2009). In all cases, the remaining ash should be recovered to reduce the overall impacts of energy recovery of waste. Fulfilment of the recovery potential will require further development and combined use of the suggested technologies.

Several factors influence the rate of environmental innovation. Park (2014a, 2014b) examined the market and regulatory factors that affect the pattern of technological innovation for waste recovery. For the paper life cycle, relevant market factors include the relative prices and quality of waste materials and their substitutes. Regulatory factors include policies and legislation for waste collection and management. Governments may mandate minimum recycling requirements or affect prices through taxation. Another barrier to technological innovation may be limited demand growth due to the recent collapse in newsprint sales and the drop in paper demand during the financial crisis (FAO 2016). Since hardly any additional production capacity is required, technological innovation may have been limited to the renewal of installed capacity.

\subsubsection{Contamination and toxicity}

Contamination control is essential for safe and functional recycling and non-energy recovery. Regarding recycling, Pivnenko et al. (2016a) suggested the following hierarchy of priorities. Ideally, contamination is prevented. For example, certain inks should not be introduced into the paper life cycle and biomass waste should not be co-fired with coal to prevent ash contamination. When contamination is not prevented, it should at least be constrained, by excluding certain waste from certain uses and avoiding mixing of waste. Separate collection is a key step in constraining contamination and leads to lower levels of rejects and higher final quality (Miranda et al. 2013). A third option is to remove contaminants during deinking but this will also remove some fibres, leading to lower pulping yields (Pivnenko et al. 2016; Stawicki and Read 2010).

Toxicity can be a problem with non-energy recovery because sludge and rejects, ash, and causticizing waste can contain high levels of hazardous trace elements. This is most problematic when contaminants get dispersed into the natural environment through composting and use as fertilizer. Landspreading of contaminated paper sludge ash may affect soil quality, water quality, human 
health, and livestock. There may also be physical contaminants such as plastics and metals

444 (Environment Agency 2015). The recovery options for mixed ash are more limited since there may be more contaminants in coal-wood ash including arsenic and lead (Park and Chertow 2014). For causticizing residuals, hazardous trace elements and residual alkali constitute barriers to recovery

447 (Kinnarinen et al. 2016; Bird and Talberth 2008).

Energy recovery of waste generates flue gases, which may contain $\mathrm{SO} 2$, NOx, dust, dioxins, furans, PAHs, and heavy metals. Good design of the combustion process can reduce the generation of pollutants. The main process variables are time, temperature, and mixing, and these should be manipulated to minimize (but rarely to fully eliminate) harmful emissions. Dioxins in flue gases, for example, can be destroyed and removed through thermal treatment and adsorption, but partly end up in the remaining ash (Lam et al. 2010). The use of appropriate chemicals for printing, coating, and bleaching as well as flue gas cleaning technologies such as electrostatic precipitators (to remove dust) also help minimize the impacts of energy recovery from waste (Suhr et al. 2015).

Demand for waste from the paper industry is limited. There is a finite capacity for using waste in cement for example, because as a low quality contaminated resource, it cannot fully substitute for virgin inputs. In addition, the paper industry sometimes has to compete with other waste suppliers. The inelasticity of supply of waste can complicate recovery: the quantity, quality, and time of generation of waste may not respond to the preferences of the user. For example, deinking sludge generation, as a joint product of paper production, follows the market demand for paper, not for sludge (Deviatkin et al. 2014; Baumgärtner 2004). Sludge also varies in quality between mills and over time for the same mill. Recovery facilities must therefore operate with flexible quality standards and the quality must be measured more frequently than for regular products.

Supply of high-quality paper for recycling is dependent on separate collection efforts because it avoids contamination with other waste (Miranda et al. 2013). The South Korean benchmark provides a successful example of a recycling infrastructure. The opportunity to recycle is provided through universal collection infrastructure and motivated through a Volume-based Waste Fee (VWF) introduced in 1995. Waste must be discarded in standardized plastics bags in order to be picked up. The bags can be purchased from local government. Recyclables are exempt from the fee and are source separated and collected from public bins at no charge. The fee on non-recyclables is supposed to incentivize consumers to shift as many recyclables as possible towards the recycling bin

474 (Park and Lah 2015; Lee and Paik 2011). Fulfilment of the recovery potential of end-of-life discards 475 requires such a system, or an equally effective one, to be implemented globally. 
476 Waste materials often have relatively low value and transport costs can be prohibitive. Transport is

477 not normally considered in the waste hierarchy but plays an important role in assessing the practical

478 and economic feasibility of waste recovery. One of the keys to industrial symbiosis is geographic

479 proximity (Chertow 2000). Jensen et al. (2011) show that waste exchanges under the National

480 Industrial Symbiosis Program (NISP) in the United Kingdom are skewed towards shorter distances.

481 Half of exchanges of paper and cardboard, compost and soils, minerals, wood products, ashes and

482 slags, and aqueous sludge are within distances of 11-108 km. Paper mills that use recycled fibre are

483 more likely to be located close to other industrial facilities and near urban areas and have many

484 opportunities for industrial symbiosis. Paper mills that rely on virgin fibre may be located in remote

485 forests where few other industries are located. In the latter case, options such as land application

486 may be more attractive than for example recovery in the construction industry.

\subsubsection{Social and cultural context}

Waste is generally perceived negatively, reflecting deeply held cultural norms regarding products, materials, and their context. The environmental hazard from waste partly stems from the disinterest of the waste holder and the prevailing culture of throwing waste away carelessly (Cheyne 2002). Waste is therefore sometimes littered, discarded in the wrong bins, or tipped. In particular, complex products that need careful handling to make sure they retain their value may be dumped in bins or left on the kerbside rather than brought to dedicated collection points. It is therefore necessary to push for careful discarding by the waste holder. The "stigmatization" of waste may be reduced by relabelling waste and specifying its value in terms of the reuse (or recovery) potential (Park 2012).

In contrast to waste, waste-based products are perceived rather positively and consumers are sometimes willing to pay more for such products than for products from virgin materials. A study of paper products by Mobley et al. (1995) suggested positive consumer attitudes towards recycled content based on an appreciation of the environmentally friendly character. The effect was only observed for paper of a well-known brand and not for paper of an unknown (fictitious) brand. Hamzaoui-Essoussi and Linton (2010) showed that willingness to pay for waste-based products decreases with perceived functional risk. An example of a product with high functional risk is food packaging because of the possibility of food contamination (Suciu et al. 2013). geographical proximity to facilitate the use of waste as a resource between companies and industries (Velenturf and Jensen 2016). A much-cited and related social factor is trust (Gibbs 2003;

507 Ashton 2008). The use of waste as a resource requires information sharing and investment in specific technologies and infrastructures. Trust enables firms to engage in such transactions with high asset 
specificity (Boons et al. 2017). Contingency plans and back-up contracts help companies deal with a defaulting supplier. The coordination of the exchange of waste as a resource should consider the embeddedness of decision making in social relationships and seek to build trust among the participants (Doménech and Davies 2011).

\subsection{Policy implications and further research}

The aforementioned barriers to waste recovery could not be incorporated in the analysis, but our results provide insights into the possibilities for the long term and exemplify a methodology that may be applied at smaller spatial scales. With better (local) data, more precise results may be calculated and used for regulatory purposes. In the EU, the Industrial Emissions Directive (IED) (EC 2010) lays down the rules for permitting industrial facilities based on Best Available Techniques (BATs). For example, the BAT for the pulp and paper industry suggests using waste as an industrial feedstock, for land spreading, or in construction materials (Suhr et al. 2015). There are, however, no quantitative estimates of the potential for using waste from the pulp and paper sector as a resource. When data allows, the BATs could be presented more usefully with the reuse or recovery potential indicator.

This study has highlighted the options for waste recovery in the global paper life cycle but without prioritizing among all options. What should decision-makers in the paper sector pursue? The waste hierarchy can provide some guidance for choosing between recycling, non-energy recovery and energy recovery but does not necessarily stimulate system-wide reductions of material use, nor does it consistently indicate lowest environmental impacts (Van Ewijk and Stegemann 2016). To choose between the different options, one might use the following performance criteria, in order of increasing difficulty of their assessment: diversion from landfill, substitution of virgin materials, reduction of individual environmental impacts, and reduction of systemic environmental impacts. The analysis in this article considered only the first two criteria based on a material flow analysis. Assessing the latter two criteria would require a life cycle assessment and is the subject of future research.

Regulation can stimulate or deter recovery. Recovery occurs more likely under flexible waste management regulation, which focuses on environmental standards instead of prescribing treatments, and strict discouragement of the lower options of the waste hierarchy (Costa et al. 2010). Waste exchange through direct government intervention has proved largely unsuccessful. Instead, "kernels" of symbiosis should be "uncovered" and supported (Chertow 2007). A case study of waste exchanges with a Finnish paper mill concluded that public policy should focus on providing the right conditions for industrial symbiosis, through the provision of knowledge and data and the 
implementation of appropriate spatial planning and land-use policies (Lehtoranta et al. 2011).

543 Regulation also has a role to play in fulfilling a variety of conditions for recovery: technological development, contamination and toxicity, supply, demand, and transport, and social and cultural context.

546 Future research may overcome the limitations of this study. Better data regarding current and potential recovery options may be obtained through industry collaboration. The calculated recovery potentials only reflect what is likely to be technically possible in 2050. Besides, the analysis has not shown the potential benefits of waste recovery beyond the confines of the paper industry. Paper waste recovery in agriculture has implications for this sector too, as well as for sectors that supply the agricultural sector. Furthermore, the analysis focused on final waste treatments within the paper

552 life cycle and ignored the potential benefits of cascading biomass use across different sectors. For 553 example, fibres could be used in timber, for paper, and as a fuel successively. There is also a potential to shift towards plants and agricultural residues as feedstocks (Bousios and Worrell 2017). Exploring all these possibilities requires a much wider system boundary and is left for future research. Finally, the approach demonstrated in this article may be applied to other material life cycles and sectors, primarily those that feature large waste streams and good data availability.

\section{Conclusions}

559 This analysis uniquely combined the concept of a "recovery potential" with a full material balance of

560 the global paper life cycle. The results show what the "ideal" paper life cycle would look like if known

561 technologies and best practices were further developed and implemented globally. The analysis

562 distinguished end-of-life discards, paper in sewage and the following industrial wastes: black liquor,

563 recycling sludge, papermaking waste, sludge and rejects, causticizing waste, and boiler ash. The

564 recovery options were categorized as recycling, non-energy recovery, and energy recovery. The results show current (2012) material flows and ideal material flows for the global paper life cycle.

566 The ideal system represents a probable technical potential in 2050. The fulfilment of the recovery 567 potential of all waste flows significantly improves the system performance. The Recycled Input Rate 568 (RIR) rises from 38\% to $67-73 \%$ and the landfill intensity decreases from $331-473 \mathrm{~kg} / \mathrm{t}$ paper to $0-2.6$

$569 \mathrm{~kg} / \mathrm{t}$ paper. Fulfilment of the recovery potential requires meeting the technical, environmental, 570 economic, and social conditions relevant to waste recovery.

571 The analysis supports the recovery of waste as a resource by giving a global overview of the recovery 572 potential of major waste flows in the global paper life cycle. The results can also be used for an 573 assessment of environmental impact reductions. Further research should seek to overcome the 
574 limitations of this study. It may consider local technical and non-technical constraints and formulate

575 a more precise potential for waste recovery. The analysis may also be improved by considering the 576 cascaded use of materials and the linkages between sectors and material life cycles.

\section{Acknowledgements}

578 The authors would like to thank Brad Upton, Daqian Jiang, Julia Stegemann, Jonathan Krones, Jon 579 Powell, and Paul Ekins for discussion and comments. 


\section{Bibliography}

Alatalo, S.M., E. Repo, E. Mäkilä, J. Salonen, E. Vakkilainen, and M. Sillanpää. 2013. Adsorption behavior of hydrothermally treated municipal sludge \& pulp and paper industry sludge. Bioresource Technology 147: 71-76.

Ashton, W. 2008. Understanding the organization of industrial ecosystems: A social network approach. Journal of Industrial Ecology 12(1): 34-51.

Baumgärtner, S. 2004. Price ambivalence of secondary resources: joint production, limits to substitution, and costly disposal. Resources, Conservation and Recycling 43(1): 95-117.

Bird, M. and J. Talberth. 2008. Waste stream reduction and re-use in the pulp and paper sector. Santa Fe.

Boons, F., M. Chertow, J. Park, W. Spekkink, and H. Shi. 2017. Industrial Symbiosis Dynamics and the Problem of Equivalence: Proposal for a Comparative Framework. Journal of Industrial Ecology 21(4): 938-952.

Bousios, S. and E. Worrell. 2017. Towards a Multiple Input-Multiple Output paper mill: Opportunities for alternative raw materials and sidestream valorisation in the paper and board industry. Resources, Conservation and Recycling 125(June): 218-232.

CEPI. 2013. CEPI Sustainability Report 2013 Summary. Brussels.

Chertow, M.R. 2000. Industrial Symbiosis: Literature and Taxonomy. Annual Review of Energy and the Environment 25(1): 313-337.

Chertow, M.R. 2007. "Uncovering" Industrial Symbiosis. Journal of Industrial Ecology 11(1): 11-30.

Cheyne, I. 2002. The definition of waste in EC Law. Journal of Environmental Law 14(2).

Costa, I., G. Massard, and A. Agarwal. 2010. Waste management policies for industrial symbiosis development: case studies in European countries. Journal of Cleaner Production 18(8): 815-822.

Deviatkin, I., A. Kujala, and M. Horttanainen. 2014. Deinking sludge utilization possibilities: technical, economic, and environmental assessments. Lappeenranta.

Doménech, T. and M. Davies. 2011. The role of Embeddedness in Industrial Symbiosis Networks: Phases in the Evolution of Industrial Symbiosis Networks. Business Strategy and the Environment 20(5): 281-296.

E4tech. 2009. Review of Technologies for Gasification of Biomass and Wastes. Biomass(June): 125.

EC. 2008. DIRECTIVE 2008/98/EC OF THE EUROPEAN PARLIAMENT AND OF THE COUNCIL of 19 November 2008 on waste and repealing certain Directives. Official Journal of the European Union.

EC. 2010. DIRECTIVE 2010/75/EU OF THE EUROPEAN PARLIAMENT AND OF THE COUNCIL of 24 November 2010 on industrial emissions (integrated pollution prevention and control). Official Journal of the ....

Ekstrand, E.M., M. Larsson, X. Bin Truong, L. Cardell, Y. Borgström, A. Björn, J. Ejlertsson, B.H. Svensson, F. Nilsson, and A. Karlsson. 2013. Methane potentials of the Swedish pulp and paper industry - A screening of wastewater effluents. Applied Energy 112(112): 507-517.

Elliott, A. and T. Mahmood. 2006. Beneficial uses of pulp and paper power boiler ash residues. Tappi Journal 5(10): 9-16. 
Emilsson, S. 2006. International Handboook From Extraction of Forest Fuels to Ash Recycling. Swedish Forest Agency.

Environment Agency. 2015. Hazards from landspreading wastes Rapid Evidence Assessment: papersludge ash.

European Biofuels Technology Platform. 2016. Dimethyl Ether (DME). Biofuel Fact Sheet.

Ewijk, S. Van and J.A. Stegemann. 2016. Limitations of the waste hierarchy for achieving absolute reductions in material throughput. Journal of Cleaner Production 132: 122-128.

Ewijk, S. Van, J.A. Stegemann, and P. Ekins. 2017. Global Life Cycle Paper Flows, Recycling Metrics, and Material Efficiency. Journal of Industrial Ecology.

FAO. 2016. FAO Stat - Forestry Production and Trade. http://faostat3.fao.org/download/F/FO/E. Accessed August 4, 2016.

Fytili, D. and A. Zabaniotou. 2008. Utilization of sewage sludge in EU application of old and new methods-A review. Renewable and Sustainable Energy Reviews 12(1): 116-140.

Gavrilescu, D. 2008. Energy From Biomass in Pulp and Paper Mills. Environmental Engineering and Management Journal 7(5): 537-546.

Gibbs, D. 2003. Trust and Networking in Inter-firm relations: the Case of Eco-Industrial Development. Local Economy 18(3): 222-236.

Hamzaoui-Essoussi, L. and J.D. Linton. 2010. New or recycled products: how much are consumers willing to pay? Journal of Consumer Marketing 27(5): 458-468.

IEA ETSAP. 2015. Pulp and Paper Industry. Technology Brief.

Jensen, P.D., L. Basson, E.E. Hellawell, M.R. Bailey, and M. Leach. 2011. Quantifying “geographic proximity": Experiences from the United Kingdom's National Industrial Symbiosis Programme. Resources, Conservation and Recycling 55(7): 703-712.

Kamali, M. and Z. Khodaparast. 2015. Review on recent developments on pulp and paper mill wastewater treatment. Ecotoxicology and Environmental Safety 114: 326-342.

Kambo, H.S. and A. Dutta. 2015. A comparative review of biochar and hydrochar in terms of production, physico-chemical properties and applications. Renewable and Sustainable Energy Reviews 45: 359-378.

Kinnarinen, T., M. Golmaei, E. Jernström, and A. Häkkinen. 2016. Separation, treatment and utilization of inorganic residues of chemical pulp mills. Journal of Cleaner Production 133: 953964.

Lam, C.H.K., A.W.M. Ip, J.P. Barford, and G. McKay. 2010. Use of incineration MSW ash: A review. Sustainability 2(7): 1943-1968.

Lee, S. and H.S. Paik. 2011. Korean household waste management and recycling behavior. Building and Environment 46(5): 1159-1166.

Lehtoranta, S., A. Nissinen, T. Mattila, and M. Melanen. 2011. Industrial symbiosis and the policy instruments of sustainable consumption and production. Journal of Cleaner Production 19(16): 1865-1875.

Mäkelä, M., V. Benavente, and A. Fullana. 2016. Hydrothermal carbonization of industrial mixed sludge from a pulp and paper mill. Bioresource Technology 200: 444-450. 
Makinen, L., A. Ammala, J. Korkko, and J. Niinimaki. 2013. The effects of recovering fibre and fine materials on sludge dewatering properties at a deinked pulp mill. Resources, Conservation and Recycling 73: 11-16.

Meier, D., B. Van De Beld, A. V. Bridgwater, D.C. Elliott, A. Oasmaa, and F. Preto. 2013. State-of-theart of fast pyrolysis in IEA bioenergy member countries. Renewable and Sustainable Energy Reviews 20: 619-641.

Meyer, T. and E.A. Edwards. 2014. Anaerobic digestion of pulp and paper mill wastewater and sludge. Water Research 65: 321-349.

Milieu Ltd. and WRc and RPA. 2013. Environmental, economic and social impacts of the use of sewage sludge on land. Final Report. Part III: Project Interim Reports: 266.

Miranda, R., M.C. Monte, and A. Blanco. 2013. Analysis of the quality of the recovered paper from commingled collection systems. Resources, Conservation and Recycling 72: 60-66.

Mobley, A.S., T.S. Painter, E.M. Untch, and H. Rao Unnava. 1995. Consumer evaluation of recycled products. Psychology \& Marketing 12(3): 165-176.

Mondi. 2014. Sustainable Development Report 2013. https://www.mondigroup.com/media/8469/mondi-sd-reportpdf_2013.pdf.

Monte, M.C., E. Fuente, a. Blanco, and C. Negro. 2009. Waste management from pulp and paper production in the European Union. Waste Management 29(1): 293-308.

Naqvi, M., J. Yan, and E. Dahlquist. 2010. Black liquor gasification integrated in pulp and paper mills: A critical review. Bioresource Technology 101(21): 8001-8015.

NETL. 2016. GASIFIERS \& GASIFICATION TECH FOR SPECIAL APPS \& ALT FEEDSTOCKS. https://www.netl.doe.gov/research/Coal/energy?systems/gasification/gasifipedia/blackliquor. Accessed September 12, 2016.

Nurmesniemi, H., R. Pöykiö, and R.L. Keiski. 2007. A case study of waste management at the Northern Finnish pulp and paper mill complex of Stora Enso Veitsiluoto Mills. Waste Management 27(12): 1939-1948.

Ouadi, M., J. Brammer, A. Hornung, and M. Kay. 2012. Waste to power. TAPPI Journal 11(2).

Ouadi, M., J.G. Brammer, M. Kay, and A. Hornung. 2013. Fixed bed downdraft gasification of paper industry wastes. Applied Energy 103: 692-699.

Park, J.Y. 2012. Wastes as Resources: The Case of Coal Combustion By-products in the United States.

Park, J.Y. 2014a. The evolution of waste into a resource: Examining innovation in technologies reusing coal combustion by-products using patent data. Research Policy 43(10): 1816-1826.

Park, J.Y. 2014b. Assessing determinants of industrial waste reuse: The case of coal ash in the United States. Resources, Conservation and Recycling 92: 116-127.

Park, J.Y. and M.R. Chertow. 2014. Establishing and testing the "reuse potential" indicator for managing wastes as resources. Journal of Environmental Management 137: 45-53.

Park, S. and T.J. Lah. 2015. Analyzing the success of the volume-based waste fee system in South Korea. Waste Management 43: 533-538.

Pivnenko, K., D. Laner, and T.F. Astrup. 2016. Material Cycles and Chemicals: Dynamic Material Flow Analysis of Contaminants in Paper Recycling. Environmental Science \& Technology 50(22): 12302-12311. 
Sankey, H.R. 1898. Introductory note on the thermal efficiency of steam-engines. Report of the committee appointed on the 31st March, 1896, to consider and report to the council upon the subject of the definition of a standard or standards of thermal efficiency for steam-en. Minutes of Proceedings of the Institution of Civil Engineers 134: 278-283.

Schmidt, M. 2008. The Sankey Diagram in Energy and Material Flow Management Part II: Methodology and Current Applications. Journal of Industrial Ecology 12(2): 173-185.

Stawicki, B. and B. Read. 2010. The Future of Paper Recycling in Europe: Opportunities and Limitations. COST Action E48.

Stoica, A., M. Sandberg, and O. Holby. 2009. Energy use and recovery strategies within wastewater treatment and sludge handling at pulp and paper mills. Bioresource Technology 100(14): 34973505.

Suciu, N.A., F. Tiberto, S. Vasileiadis, L. Lamastra, and M. Trevisan. 2013. Recycled paper-paperboard for food contact materials: Contaminants suspected and migration into foods and food simulant. Food Chemistry 141(4): 4146-4151.

Suhr, M., G. Klein, I. Kourti, M. Rodrigo Gonzalo, G. Giner Santonja, S. Roudier, and L. Delgado Sancho. 2015. Best Available Techniques ( BAT ) Reference Document for the Production of Pulp, Paper and Board.

Universiteit Twente. 2015. Re-use of paper sludge via pyrolysis. https://www.utwente.nl/en/news/!/2015/6/265531/re-use-of-paper-sludge-via-pyrolysis. Accessed January 11, 2017.

UPM. 2015. Environmental performance in 2015. http://assets.upm.com/Responsibility/Documents/EMAS2015/Pietarsaari_EMAS_2015_EN.pdf. Accessed December 2, 2016.

UPM. 2016. UPM PURSUES ZERO SOLID WASTE TO LANDFILL STATUS BY 2030. Biofore. https://www.upmbiofore.com/upm-pursues-zero-solid-waste-to-landfill-status-by-2030/. Accessed December 9, 2016.

Vadenbo, C., S. Hellweg, and T.F. Astrup. 2017. Let's Be Clear(er) about Substitution: A Reporting Framework to Account for Product Displacement in Life Cycle Assessment. Journal of Industrial Ecology 21(5): 1078-1089.

Velenturf, A.P.M. and P.D. Jensen. 2016. Promoting Industrial Symbiosis: Using the Concept of Proximity to Explore Social Network Development. Journal of Industrial Ecology 20(4): 700-709.

Wiechmann, B., C. Dienemann, C. Kabbe, S. Brandt, I. Vogel, and A. Roskosch. 2013. Sewage Sludge Management in Germany. Umweltbundesamt. 


\section{A. Waste generation}

737

The figures for waste generation are calculated in four steps. First, the following flows are taken from Van Ewijk et al. (2017): end-of-life discards and papermaking waste. Second, the waste from chemical pulping and the waste from mechanical pulping are further detailed and combined in the following flows:

- Black liquor is the proportion of chemical pulping waste that is not a by-product or part of sludge and rejects.

- By-products are mainly tall oil and turpentine. By-products are produced at 10-75 (50 typical) kg/t pulp (Suhr et al. 2015, p. 204).

- Sludge and rejects consist of two fractions of chemical pulping waste and all of the mechanical pulping waste. The two fractions of chemical pulping waste are Waste Water Treatment Plant (WWTP) residuals, produced at a rate of $10 \mathrm{~kg} / \mathrm{t}$ pulp (Suhr et al. 2015, p. 250 ), and screening rejects, produced at a rate of 2-20 (used value 11 ) $\mathrm{kg} / \mathrm{t}$ pulp (Suhr et al. 2015, p. 251).

Third, causticizing waste consists of losses from the chemical recovery cycle and is compensated for with lime-make up. This flow is included as both an input and an output and leads to a larger overall waste generation than in Van Ewijk et al. (2017). It is not part of chemical pulping waste because it results from a separate process. Causticizing waste is produced at an average rate of $30 \mathrm{~kg} / \mathrm{t} \mathrm{pulp}$ and varies between 10 and $60 \mathrm{~kg} / \mathrm{t}$ pulp (Suhr et al. 2015, p. 251).

Last, ash is included as a secondary waste from waste combustion and included as both an input and an output in the material balance. The quantity of boiler ash follows from the ash content of waste used for energy recovery, based on the following assumptions.

- Sludge and rejects: $10 \%$ ash content. This is a rough approximation based on the ash content of mechanical pulping sludge ( $2 \%$ based on wood), Kraft screening rejects ( $10 \%)$, and WWTP solids (20\%) (Gavrilescu 2008; Suhr et al. 2015).

- Recycling sludge: $45 \%$ ash content (Suhr et al. 2015).

The resulting waste flows are detailed in Appendix D. 


\section{B. Waste treatments}

764

765

766

767

The treatment of end-of-life discards, papermaking waste, and paper in sewage is discussed in Van Ewijk et al. (2017). The waste treatment of the other waste flows is calculated using the following procedure.

1. Taking the total waste treatment intensities in $\mathrm{kg} / \mathrm{t}$ paper for non-energy recovery and landfill from Van Ewijk et al. (2017).

2. Estimating the fractions of non-energy recovery, energy recovery, and landfill for sludge and rejects, causticizing waste, and boiler ash based on the literature.

3. Calculating the quantities of boiler ash based on ash content of the relevant waste and the fraction of industrial waste to energy recovery.

4. Calculating the treatment fractions for recycling sludge by balancing waste treatment of all other flows, ash generation, and total waste treatment.

Because the data are very uncertain, the waste treatment fractions are rounded to quarters, except for the case of recycling sludge, since this is calculated from final differences. Below, the individual waste flows are discussed (step 2 and 4).

Sludge and rejects

Sludge and rejects cover mechanical pulping losses, Kraft rejects, and Kraft WWTP residuals. These waste streams can also be categorized as WWTP residuals because they are suspended solids that first go through wastewater treatment. Bird and Talberth (2008) present data for WWTP residuals from a 2002 study by the American Paper and Forestry Association which suggests that 52\% of the waste is landfilled, $22 \%$ is used for energy recovery, and $26 \%$ is applied to land or used for other non-energy recovery operations. It is assumed that globally one quarter is used for energy recovery and one quarter is used for non-energy recovery.

\section{Causticizing waste}

Bird and Talberth (2008) present US data gathered by NCASI for 1995 which shows $70 \%$ of lime mud, $95 \%$ of dregs, and $91 \%$ of grits go to landfill (or lagoon). Overall, $81 \%$ of these materials were landfilled. Data from the Finnish Forest Industries collated by Kinnarinen et al. (2016) suggest that $71 \%$ of dregs were landfilled in Finland in 2012. If the landfill rates of lime mud and grits have similarly improved, total causticizing waste landfill rates would be $61 \%$ in $2012(71 / 95 * 81=61)$. However, the Finnish data most certainly represent an above average performance. It is assumed that approximately three quarters of global causticizing waste are landfilled. 
795 The American Forestry and Paper Association (AF\&PA) presented a report in 2002 which shows that 796 about one third of boiler ash is recovered (Bird and Talberth 2008). In Canada, in 2002, about 80\% of 797 ash from pulp and paper mills was landfilled (Elliott and Mahmood 2006). In 2003, over half of wood 798 ash from the pulp and paper industry in Finland was utilised (Emilsson 2006). Finland probably 799 performs well above the global average, partly because of very little mixing of wood ash with coal 800 ash. It is assumed that approximately half of wood and sludge ash from pulp and paper mills is used 801 in non-energy recovery in 2012.

\section{Recycling sludge}

803 Recycling sludge is the largest industrial waste fraction after black liquor from chemical pulping. The 804 treatment fractions are based on the differences between final treatments of the total industrial 805 waste flow based on the overall waste treatment intensities in Van Ewijk et al. (2017) and the waste 806 treatment of causticizing waste, boiler ash, and sludge rejects as described above. The calculation 807 includes secondary waste in the form of ash from energy recovery. This implies that any increase in 808 energy recovery entails an increase in the amount of waste that needs final treatment. The resulting fractions are $8 \%$ energy recovery and $50 \%$ non-energy recovery. 
811 The recovery potential (RP) for recycling is not calculated as a recycling rate (RR) because it needs to consider inevitable losses due to additions to stock and paper in sewage. The RP also distinguishes between papermaking waste and end-of-life discards. The description of the RR and RP are as follows:

- The RR divides total paper for recycling collection by total consumption. It includes paper for recycling from the pulp, paper, and print industry (papermaking waste) and from consumers.

- The fulfilment of the RP for end-of-life discards indicates the fraction of potentially recyclable end-of-life discards that is recycled. End-of-life discards consist of total consumption minus net additions to stock and paper in sewage.

- The fulfilment of the RP for papermaking waste indicates the fraction of papermaking waste that is recycled. Papermaking waste is calculated based on the yield ratio of papermaking.

The fulfilment of the potential for recycling of end-of-life discards can be calculated from the recycling rate based on the flow quantities detailed in Appendix D. The RR can be calculated as follows:

$$
R R=\frac{F 25+F 15+F 17+F 19+F 21}{F 22+F 23+F 24}
$$

The RP for end-of-life discards and papermaking waste is 1.00. The actual quantity of recycling under fulfilment of the RP can be calculated with the following two equations.

$$
R P_{\text {EoL discard }}=F 24 * 1.00
$$

$$
R P_{\text {papermaking waste }}=(F 15+F 17+F 19+F 21) * 1.00
$$

The current performance for recycling of end-of-life discards is lower than the potential. The fulfilment of the potential can be calculated as follows.

$$
R P_{\text {EoL discard }}^{\text {fulfilled }}=F 25 / F 24
$$

833 Based on the above, an RR of 0.91, as for South-Korea, can be converted to a figure for the RP 834 fulfilment. Consumption is assumed to be a 100 units. The calculation starts with distinguishing the papermaking waste (PMW) based on the yield ratio of papermaking of 0.95 (Van Ewijk et al. 2017).

837 Now the amount of end-of-life discard that is recycled can be calculated, assuming PMW is fully recycled. 
840 Availability of end-of-life discards follows from net additions to stock and losses of toilet paper in

841 sewage (TP) of 0.09 and 0.03 respectively (Van Ewijk et al. 2017).

$$
E o L_{\text {discard }}=100 *(1-N a S-T P)=88
$$

843

$$
R P_{\text {EoLdiscard }}^{\text {fulfilled }}=\frac{86}{88}=0.97
$$

844 In conclusion, the benchmark for fulfilment of the recovery potential for recycling of end-of-life 845 discards is 0.97 . 
Table D.1: Detailed normalized current and ideal flows (for the base year 1 unit $=4 \mathrm{Mt}$ ).

\begin{tabular}{|c|c|c|c|c|}
\hline Flow & Input & Output & Current & Ideal \\
\hline F1 & Virgin fibre & Mechanical pulping & 8.7 & 4.1 \\
\hline F2 & Virgin fibre & Chemical pulping & 78.3 & 36.4 \\
\hline F3 & Paper for recycling (in) & Recycled pulping & 53.9 & 93.3 \\
\hline F4 & Mechanical pulping & Mechanical pulp & 8.1 & 3.8 \\
\hline F5 & Mechanical pulping & Sludge and rejects & 0.6 & 0.3 \\
\hline F6 & Chemical pulping & Chemical pulp & 37.6 & 17.5 \\
\hline F7 & Chemical pulping & Black liquor & 38.0 & 17.7 \\
\hline F8 & Chemical pulping & By-products & 1.9 & 0.9 \\
\hline F9 & Chemical pulping & Sludge and rejects & 0.8 & 0.4 \\
\hline F10 & Lime makeup & Recovery cycle & 1.1 & 0.5 \\
\hline F11 & Recovery cycle & Causticizing waste & 1.1 & 0.5 \\
\hline F12 & Recycled pulping & Recycled pulp & 43.7 & 68.1 \\
\hline F13 & Recycled pulping & Recycling sludge & 10.2 & 25.2 \\
\hline F14 & Recycled pulp & Consumption & 41.5 & 64.7 \\
\hline F15 & Recycled pulp & Papermaking waste & 2.2 & 3.4 \\
\hline F16 & Chemical pulp & Consumption & 35.7 & 16.6 \\
\hline F17 & Chemical pulp & Papermaking waste & 1.9 & 0.9 \\
\hline F18 & Mechanical pulp & Consumption & 7.7 & 3.6 \\
\hline F19 & Mechanical pulp & Papermaking waste & 0.4 & 0.2 \\
\hline F20 & Non-fibrous & Consumption & 15.1 & 15.1 \\
\hline F21 & Non-fibrous & Papermaking waste & 0.8 & 0.8 \\
\hline F22 & Consumption & Stock & 9.0 & 9.0 \\
\hline F23 & Consumption & Paper in sewage & 3.0 & 3.0 \\
\hline F24 & Consumption & End-of-life discards & 88.0 & 88.0 \\
\hline F25 & End-of-life discards & Recycling & 48.6 & 88.0 \\
\hline F26 & End-of-life discards & Energy recovery & 4.7 & 0.0 \\
\hline F27 & End-of-life discards & Incineration & 3.1 & 0.0 \\
\hline F28 & End-of-life discards & Landfill & 31.5 & 0.0 \\
\hline F29 & Paper in sewage & Non-energy recovery & 1.2 & 0.0 \\
\hline F30 & Paper in sewage & Energy recovery & 0.4 & 3.0 \\
\hline F31 & Paper in sewage & Incineration & 0.2 & 0.0 \\
\hline F32 & Paper in sewage & Landfill & 1.2 & 0.0 \\
\hline F33 & Black liquor & Energy recovery & 38.0 & 17.7 \\
\hline F34 & Recycling sludge & Non-energy recovery & 5.2 & 21.7 \\
\hline F35 & Recycling sludge & Energy recovery & 0.8 & 3.5 \\
\hline F36 & Recycling sludge & Landfill & 4.3 & 0.0 \\
\hline F37 & Papermaking waste & Paper for recycling (out) & 5.3 & 5.3 \\
\hline F38 & Sludge and rejects & Non-energy recovery & 0.3 & 0.3 \\
\hline F39 & Sludge and rejects & Energy recovery & 0.3 & 0.3 \\
\hline F40 & Sludge and rejects & Landfill & 0.7 & 0.0 \\
\hline F41 & Causticizing waste & Non-energy recovery & 0.3 & 0.4 \\
\hline F42 & Causticizing waste & Landfill & 0.8 & 0.1 \\
\hline F43 & Secondary & Boiler ash & 0.4 & 1.6 \\
\hline F44 & Boiler ash & Non-energy recovery & 0.2 & 1.6 \\
\hline F45 & Boiler ash & Landfill & 0.2 & 0.0 \\
\hline
\end{tabular}

